\title{
Me-Generation: The New Culture of Consumerism
}

\author{
Sisodia Devendra Singh*
}

\section{ABSTRACT:}

In the present era of free trade subject of consumerism is of prime concern. In the materialistic world consumerism plays vital role, increase in purchasing power with wide range of consumer items relating to new satisfaction of materialistic needs has led to a vast number of people availing of these opportunities in changing their whole lifestyle. A study was undertaken on a sample to see the change in value norms. The emerging value system would be of immediate need satisfaction "success" the key word of the "me generation", the term popularly used for members of the new culture of consumerism.

Keywords: Me- Generation, Consumerism, Materialistic World, Consumption, Success, Sociogenic Traits, Behavioural Mode, Value System, Free Trade.

\section{INTRODUCTION}

The present era is one of free trade and economic development. Most countries are now liberalizing and throwing open their economy, in order to raise the level of economic functioning. The main aim in the majority of cases is to raise the standard of living, raise people's purchasing power especially of those below the poverty line: raise the level of finances available with institutions for welfare and defence purposes. The fact remains that industrial growth is found necessary at this stage, for several nations, including India. India too is gearing up for all this, making efforts to join the global economic community and trying to reach a level of economic functioning equal to any global economy. Thus India too, faces a growing economy, with aims being consequently achieved.

Industrial growth, especially in India, is based upon increasing industrial production through conducive conditions of market and government regulations.

This in turn provides more employment and purchasing power which in turn provides more purchasing and hence, finally more demand for product and more production-industrial growth. This is a basic tenant of economic theory. This raises the problem that there will be an increase in the use of consumer goods in India which have traditionally not been available and in use.

*Head, Department of Psychology, BN Girls College, MLS University, Udaipur

(C) 2014 S Singh; licensee IJIP. This is an Open Access Research distributed under the terms of the Creative Commons Attribution License (http://creativecommons.org/licenses/by/2.0), which permits unrestricted use, distribution, and reproduction in any Medium, provided the original work is properly cited. 
The Indian culture is a phenomenon having wide variety and diversity. But the essential ingredients have been the same that is the unifying factor integrating the vast number of geographic and political units. The value system, orientation and different consumption strata have been essentially the same, so have the social institutions of caste, occupation, cognition, et al., including standard of living strata, all this is, in effect, brought about by the socialization, which moulds individual behaviour, into conformity with social norms, values and objectives or motives. Individually, thus it develops a behavioural mode determing a set pattern of behavior in terms of values, attitudes, cognitions, perceptions, alternative modes of action, aspiration and achievement levels. Consequently a typical set of need satisfaction patterns and a self identity of the individual are developed. It goes with the self identity that several covert factors determine the identity and thus selected behavioural mode of the individual. This is constantly referred by the individual in his effort to confirm his actual reality, self image and real image.

This external confirmation of the behavioural mode is usually in terms of items of consumption. This reflects both his need satisfaction pattern and his achievement level. These are the crux of what is happening to the behavioural mode. One indicator of the casual psychological factors for these behaviours is the cognitive organization of individuals termed values.

'Consumerism' is the term given to the new cultural phenomenon of spending a greater part of the income on consumption of items than on saving or investing, unlike Keynesian assumptions, instead of an increase in consumption and expenditure. This has been confirmed in the NCAER household consumption data survey (2012).

This is intrinsically linked to individual values; need structure and hence actual consumption patterns. These three variables have been chosen as a basis of measuring behavioural modes.

The emerging trends as sociogenic traits which are a resultant of social processes. Further if these sociogenic traits are predominant and enduring as inferred by cross sectional data then these may be taken to reflect cultural trends, related to achievement orientation, values of success, need gratification and so on.

\section{METHOD AND PROCEDURE}

The research problem is thus to study the trends in behavioural modes in a cross sectional sample and to find out if there emerges any cultural factors showing a change in terms of consumerism.

The objective is thus to study the variables grouped under the behavioural mode, and to find out if any inferences can be made from this data set and analysis with regard to sociogenic traits and cultural identity factor. The design was therefore constructed to reflect a change in cultural identity where a cross-sectional sample is more feasible here than a longitudinal study. Thus one independent variable is age other is ' $n$ ' achievement as a relevant and rather influential factor affecting consumerism. The dependent variable was the behavioural mode. This is defined here operationally as "the total score of the values need structure and consumption pattern".

Sample was chosen with age group less than 21 years to represent new generation which is culturally different from the other age group of above 45 years with more traditional values. 
Achievement criterion was above $70 \%$ academic achievements on an average and below $50 \%$ same for high and low achievement respectively. It was hypothesized that there would be no significant differences between high and low "n" achievement with respect to behavioral mode. Further there would be no significant differences between older and younger groups with regard to behavioural mode. The methodology comprised development of an S. D. T. based tool for discriminating between the three criterions of usefulness, need structure frequency of use consumption pattern and value or desirability consumption values on a list of items. These items were chosen on the basis of economic data regarding availability and consumption expenditure volumes and trends with regard to all classes of consumption items like food, clothing, durable goods, etc ( sources C. S. O., CMIE, publications, NCAER National household surveys, Indian economic information Year books, et al. India,2013).

\section{RESULTS}

\begin{tabular}{|l|l|l|l|l|l|l|l|l|l|}
\hline & C.V. & C.P. & N.S. & B.M. & & C.V. & C.P. & N.S. & B.M. \\
\hline High & 73 & 69 & 71 & 213 & & 68 & 53 & 54 & 175 \\
\hline Low & 56 & 72 & 71 & 199 & & 58 & 56 & 56 & 169 \\
\hline
\end{tabular}

Mature Adults (More Than 45 Years)

Age

Youth (Less Than 21 Years)

Where:
C.V. = Consumption Values
C.P. $=$ Consumption Pattern
N.S. $=$ Need Structure
B.M. = Behavioural Mode

\section{DISCUSSION AND INTERPRETATION:}

From the above table several trends emerge. The foremost was that, the mature adults group scores of behavioural mode are generally higher than that of youth group scores, irrespective mode was generally higher than youth group scores, irrespective of the influence of independent variable ' $n$ ' achievement.

A possible explanation of mature age group in both blocks of " $n$ " achievement achieving higher behavioural mode scores than youth group of both blocks of " $n$ " achievement may be that they may be more used to a consumption pattern which has grown over the years and their established professional or public life requires use of such items. One factor may be that values regarding the respect and priority of consumption given to age in Indian society are still alive.

Further, an analysis of behavioural mode constituents show that mature adults group score nearly the same in consumption values in their respective " $n$ " achievement blocks, while their score in consumption pattern is far higher than youth group scores, thus inflating the behavioural mode scores comparatively. This may be explained by the fact that in a single income group, the mature adults group members of a family are the priority and high frequency users of most 
consumer items and consider the durables and convenience items as essential while youth group respondents in the same family and income groups do not yet have the same necessity and frequency of use of these said items. Thus their score may be lower than the mature adults group in items of need structure and consumption pattern but in term of value their scores are higher.

As far as " $n$ " achievement goes there is a confirmation of generally observed trend that high achievement Need Level goes with higher achievement in consumption pattern, a higher level of need and values indicating a higher level of consumption. In terms of consumption values there is a large difference in the mature adults group showing a wide gulf between high and low " $n$ " achievement groups in this age group.

This may be the real indicator of conflicting cultural values of traditionally low materialistic need satisfaction versus the high materialistic need satisfaction pattern. Further one sees the gap narrowing for youth group. This trend shows that whatever the consumption pattern and need structure, the consumption value gap is less in mature adults group for low and high " $n$ " in sample. This Trend shows the spread of materialistic values in the younger age group.

Thus there is definite shift in values from conservative to what can only be termed as materialistic. What emerges from these behavioural mode scores is that the value system is showing changes in overall and so is the need structure, as seen from the aggregate scores.

The last discussed trend of difference in the gap of high and low " $n$ " achievement groups in both age groups, seems to indicate that apart from consumption values, the value system seems to be changing. The specific culture wide changes that seem apparent are that " $n$ " achievement levels are increasing especially with respect to consumption items. This is possibly a matter for further exploration with greater operational controls and more in depth definition.

This emerging trend seems to confirm the work of Tom Wolf (1976) in calling the newly emerging consumerist or materialistic generation as the "me generation" which has high consumption values and also aims at achieving those consumption values and need structure scores irrespective of present consumption pattern levels.

What is definitely concluded is that there is an increasing aspiration level for higher standard of living, inspite of insignificant relationship in most of the cell blocks in the present study, which may be casual or concomitant variables of higher economic growth level of functioning according to Galbraith in the affluent society. 


\section{REFERENCES:}

1. Anderson Bany (1975) "Cognitive Psychology", Academic Press, London.

2. Gupta R.D (1999) "Keynes; Post Keynesian Economics", Gupta Prakashan, Agra.

3. Katona George (2004) "Consumer Decisions Processes", Prentice Hall, London.

4. Kerlinger (1983) "Foundation of Behavioural Research" Surjeet publication, Delhi.

5. Loudon and Della Bitta, (2009) .Consumer Behavior, Concepts and Applications ISE, McGraw Hill, New York.

6. Margin, (2012) NCAER Publications.

7. Newcomb Turner (2009) Converse "Social Psychology", Routledge and Kegan Paul Ltd., Britain.

8. Samuelson P. E. (2013) "Economics" McGraw Hill, New York.

9. Wolf Tom (1976) "Self Identity Journal of Applied Psychological Research". 